Jurnal Agro 7(2), 2020

\title{
EFEK INOKULASI PGPR TERHADAP PERTUMBUHAN TANAMAN PADI FASE VEGETATIF DI MEDIA SALINITAS TINGGI
}

\section{THE EFFECT OF PGPR INOCULATION ON THE RICE GROWTH AT VEGETATIVE PHASE IN MEDIA WITH HIGH SALINITY}

\author{
Eka Junianti ${ }^{1}$, Elly Proklamasiningsih ${ }^{1}$, Purwanto $^{2 *}$ \\ ${ }^{1}$ Fakultas Biologi, Universitas Jenderal Soedirman Purwokerto \\ ${ }^{2}$ Fakultas Pertanian, Universitas Jenderal Soedirman Purwokerto \\ Jl. dr Suparno KP 125 Purwokerto 53122 \\ *Korespondensi: purwanto.unsoed@gmail.com
}

Diterima : 25 Maret 2020 / Disetujui : 4 Desember 2020

\begin{abstract}
ABSTRAK
Rhizobakteria merupakan kelompok bakteri yang hidup di perakaran tanaman yang bermanfaat bagi pertumbuhan tanaman melalui kemampuan menghasilkan IAA. Rhizobakteria dapat hidup di berbagai kondisi lingkungan, salah satunya di lahan salin. Tujuan penelitian ini untuk mengkaji efek Plant-Growth Promoting Rhizobacteria bagi tanaman padi pada fase vegetatif di media dengan silinitas tinggi, dan mendapatkan isolat yang paling efektif meningkatkan pertumbuhan vegetatif padi varietas Inpari Unsoed 79 Agritan. Penelitian ini dilakukan di Laboratorium Agronomi dan Hortikultura, dan Screenhouse Experimental Farm Fakultas Pertanian UNSOED pada bulan Oktober 2019-Januari 2020. Rancangan penelitian yang digunakan adalah Rancangan Acak Kelompok Lengkap dengan 6 perlakuan dan diulang 4 kali. Perlakuan pada penelitian ini antara lain kontrol, JA2, JB1, JB2, JD1, dan JE1 pada medium cair $A B$ Mix dengan tingkat salinitas $5 \mathrm{dSm}^{-1}$. Inokulasi PGPR meningkatkan pertumbuhan tanaman padi pada fase vegetatif. Bobot kering tanaman, panjang akar, kehijauan daun, luas daun, tinggi tanaman masing-masing meningkat sebesar 130\%, 108\%, 19\%, 50\%, 21\% dengan inokulasi PGPR pada medium dengan salinitas tinggi.
\end{abstract}

Kata kunci: Padi, pertumbuhan, PGPR, salin, vegetatif

\section{ABSTRACT}

Rhizobacteria are a group of bacteria that live in rhizozphere of plant which are beneficial for plant growth through the ability to produce IAA. Rhizobacteria can live in various environmental conditions, one of which is in saline fields. The research goal was to study the effect of PGPR for rice plants in the vegetative phase in high salinity media and to find the most effective isolates in increasing vegetative growth of Inpari Unsoed 79 Agritan rice. This research was conducted at the Agronomy and Horticulture Laboratory, and the screenhouse of Experimental Farm, Faculty of Agriculture, UNSOED in October 2019-January 2020. This research was arranged by

Cite this as: Junianti, E., Proklamasiningsih, E. \& Purwanto. (2020). Efek inokulasi PGPR terhadap pertumbuhan tanaman padi fase vegetative di media salinitas tinggi. Jurnal Agro, 7(2), 193-203. https://doi.org/10.15575/8057 
using a Randomized Complete Block Design and repeated 4 times. The treatments in this study included control, JA2, JB1, JB2, JD1, and JE1 in AB Mix liquid medium with a salinity level of 5 $\mathrm{dSm}^{-1}$. The inoculation of rhizobacteria can increase the rice plant growth at vegetative phase. The plant biomass, root length, leaf greenness, leaf area, plant height increased by $130 \%, 108 \%$, $19 \%, 50 \%, 21 \%$ respectively by PGPR inoculation of medium with high salinity.

Key words: Rice, PGPR, growth, vegetative, saline

\section{PENDAHULUAN}

Padi merupakan komoditas utama sebagai sumber pangan pokok masyarakat Indonesia(Fardhani et al., 2018). Tingkat ketergantungan masyarakat Indonesia terhadap beras mencapai 92-95\% (Maulina et al., 2015). Tingginya kebutuhan beras di Indonesia tidak seimbang dengan luasnya lahan pertanian yang tersedia. Lahan-lahan pertanian yang subur dialih fungsikan sebagai industri, perumahan, dan infrastruktur. Masifnya konversi lahan pertanian ini akan mengancam ketahanan pangan (Kusumastuti et al., 2018). Oleh karena itu, ekstensifikasi lahan perlu dilakukan dengan memanfaatkan lahan marjinal yang potensial untuk tanaman padi sperti lahan salin (Arrosyid \& Sugito, 2018).

Lahan salin merupakan lahan marginal dengan kadar garam tinggi dan memiliki produktivitas rendah akibat rendahnya kualitas tanah (Zulaikha \& Yuliani, 2011). Menurut (Cahyaty et al., 2017) sekitar 9,5 juta hektar lahan salin di Indonesia potensial dijadikan sebagai lahan pertanian, namun produksinya rendah. Tanah salin dengan nilai konduktivitas listrik (EC) di atas $6 \mathrm{dS} . \mathrm{m}^{-1}$ berpotensi kehilangan $50 \%$ dari hasil padi (Athallah et al., 2018). Lahan ini memiliki kadar garam tinggi berupa $\mathrm{Na}, \mathrm{Ca}$, $\mathrm{Mg}$, dalam bentuk klorida atau sulfat yang dapat menyebabkan defisiensi N, P, Mn, Fe tanah, stress osmotik, menghambat penyerapan air dari tanah dan dapat bersifat toksik bagi tanaman (Sulasih \& Widawati, 2016; Subowo, 2015; Shrivastava \& Kumar, 2015). Cekaman salinitas mengakibatkan terganggunya pertumbuhan, produktivitas tanaman pertanian, dan terganggunya fungsi fisiologis tanaman secara normal (Sulasih \& Widawati, 2016).

Produktivitas padi di Indonesia perlu ditingkatkan untuk memenuhi kebutuhan nasional dengan memanfaatkan lahan salin dan memperbaiki pertumbuhan tanaman, termasuk melalui penggunaan PGPR. PGPR merupakan suatu kelompok mikroorganisme yang hidup di daerah rhizosfer dan mengkoloni akar (Habibi et al., 2019), pada area 1-2 cm sekitar perakaran (Kurniahu et al., 2018). Menurut Zerrouk et al. (2019) PGPR mampu menghasilkan IAA yang termasuk golongan auksin yang menginduksi poliferasi dan diferensiasi sel, serta menstimulasi pertumbuhan. Beberapa genus rhizobakteri PGPR yaitu Pseudomonas, Azospirilum, Azotobacter, Bacillus dan Serratia (Maulina \& Darmayasa, 2018). Bakteri PGPR dapat hidup di berbagai kondisi, salah satunya di lahan salin (Nghia et al., 2017).

Penggunaan PGPR indigenous lahan salin dapat memperbaiki pertumbuhan tanaman (Maulina \& Darmayasa, 2018), selain itu dapat meningkatkan pertumbuhan vegetatif tanaman pada kondisi tercekam salinitas (Zainudin et al., 2014). Fauzan (2018) menemukan isolat 
JA2, JB1 JB2, JD1, dan JE1 yang merupakan bakteri PGPR indigenous lahan salin dan mampu menghasilkan IAA. Aplikasi PGPR indigenous lahan salin terhadap tanaman padi akan meningkatkan produksi padi di lahan salin. Penelitian ini bertujuan untuk mengkaji efek Plant-Growth Promoting Rhizobacteria bagi tanaman padi pada fase vegetatif di media dengan silinitas tinggi, dan mendapatkan isolat yang paling efektif meningkatkan pertumbuhan vegetatif padi varietas Inpari Unsoed 79 Agritan.

\section{BAHAN DAN METODE}

Penelitian dilakukan di Lab. Agronomi dan Hortikultura, dan Screenhouse Experimental Farm Fakultas Pertanian UNSOED pada bulan Oktober 2019-Januari 2020. Peralatan yang digunakan Antara lain timbangan analitik, magnetic stirrer, autoklaf, tabung reaksi, cawan petri, Laminar Air Flow (LAF), klorofil meter (SPAD), Total Solid Dissolved (TDS) meter, Electrical Conductivity (EC) meter, erlenmeyer, jarum ose, oven, shaker, $\mathrm{pH}$ meter, baki, jerigen $10 \mathrm{I}$, dan milimeter blok. Bahan penelitian ini Antara lain isolat PGPR indigenous lahan salin yaitu isolat JA2, JB1, JB2, JD1, JE1, benih padi Inpari unsoed 79 agritan, medium Nutrien Agar (NA), molase $5 \%$, akuades, $\mathrm{NaCl}, \mathrm{NaClO}$, dan medium cair AB Mix.

Penelitian ini dirancang dengan Rancangan Acak Kelompok Lengkap (RAKL) dan diulang 4 kali. Perlakuan yang dicoba antara lain kontrol (tanpa inokulasi PGPR), isolat JA2, isolat JB1, isolat JB2, isolat JD1, dan isolat JE1. Sebagai tanaman uji digunakan padi varietas Inpari Unsoed 79 Agritan yang ditanam di medium cair $A B$ Mix dengan tingkat salinitas sebesar $5 \mathrm{dSm}^{-}$ 1.
Kultur stok bakteri dibuat dengan melarutkan molase $5 \%$ dalam $1 \mathrm{~L}$ akuades. Molase dimasukkan dalam 10 erlenmeyer dengan volume masing-masing $100 \mathrm{~mL}$. Setiap erlenmeyer kemudian diinokulasikan isolat PGPR sebanyak 2 ose, selanjutnya di shaker dengan kecepatan 180 rpm selama 3 hari. Kultur stok disimpan dalam refigerator setelah digunakan. Larutan AB Mix dibuat konsentrasi 1100 ppm dalam 4 L air, selanjutnya diberi perlakuan $\mathrm{NaCl} 5 \mathrm{dSm}^{-1}$ dan diinokulasikan isolat sebanyak $2 \mathrm{~mL}$ dengan kepadatan isolat JA2, JB1, JB2, JD1, dan JE1 masing-masing adalah $3,50 \times 10^{7}$ $\mathrm{CFU} \mathrm{mL}{ }^{-1}, 3,75 \times 10^{8} \mathrm{CFU} \mathrm{mL}^{-1}, 5,45 \times 10^{8} \mathrm{CFU}$ $\mathrm{mL}^{-1}, 1,13 \times 10^{9} \mathrm{CFU} \mathrm{mL}^{-1}$, dan $5,65 \times 10^{8} \mathrm{CFU}$ $\mathrm{mL}^{-1}$. Konsentrasi larutan dipertahankan 1100 ppm, dengan EC 5 dSm $^{-1}$, dan pH 5,56,5. Pemberian $\mathrm{NaCl}$ sebesar $5 \mathrm{dSm}^{-1}$ dan inokulasi bakteri dilakukan saat tanaman telah berumur 2 minggu dan diperbaharui seminggu sekali. Variabel yang diamati yaitu total panjang akar, bobot brangkasan kering tanaman, luas daun, dan kehijauan daun, dan tinggi tanaman padi. Data hasil penelitian diuji menggunakan Uji $F$, dan apabila hasil uji $\mathrm{F}$ menunjukkan hasil nyata, dilanjutkan DMRT $\alpha=5 \%$.

\section{HASIL DAN PEMBAHASAN}

Aplikasi isolat PGPR seluruhnya mampu meningkatkan pertumbuhan vegetatif tanaman dibandingkan dengan kontrol (tanpa inokulasi isolat), tetapi antar isolat belum menunjukkan perbedaan yang signifikan. Perlakuan isolat mampu meningkatkan tinggi tanaman, luas daun, kehijauan daun, total panjang akar, dan bobot brangkasan tanaman. Hal ini dikarenakan isolat yang digunakan hidup pada tingkat salinitas dan nutrisi yang sama, sehingga dimungkinkan kemampuan isolat 
dalam memproduksi zat pengatur tumbuh tidak jauh berbeda. Sesuai dengan pernyataan (Fauzan, 2018), isolat PGPR yang diperoleh diambil dari tingkat salinitas sedang hingga tinggi, yaitu $0,8-5 \mathrm{dSm}^{-1}$, dengan $\mathrm{pH}$ tanah hampir sama yaitu $\mathrm{pH} 6,1-$ 6,8 dan seluruh isolate.

Inokulasi isolat PGPR indigenous lahan salin mampu meningkatkan panjang dan bobot kering akar jika dibandingkan dengan kontrol, tetapi antar isolat tidak ada perbedaan pengaruh (Tabel 1). Inokulasi isolat PGPR dapat meningkatkan panjang akar hingga $108 \%$ dan bobot kering akar hingga $149 \%$ pada pengamatan 8 msp.
Isolat PGPR yang mengkolonisasi perakaran memiliki dampak positif bagi tanaman karena memiliki kemampuan mensintesis asam amino yang dihasilkan oleh eksudat akar berupa L-tryptophan yang merupakan prekursor dari hormon IAA, sehingga mampu membantu pertumbuhan tanaman dan meningkatkan serapan hara (Anggarwulan et al., 2008). Menurut Dewi et al. (2015), mikroba penghasil IAA menstimulasi pertumbuhan akar yang menyebabkan luas permukaan akar meningkat sehingga air dan unsur hara yang terserap menjadi lebih banyak.

Tabel 1. Pengaruh inokulasi PGPR indigenous lahan salin terhadap panjang dan bobot kering akar tanaman padi

\begin{tabular}{ccccccccc}
\hline Per- & \multicolumn{4}{c}{ Panjang Akar (cm) } & \multicolumn{3}{c}{ Bobot kering Akar (g) } \\
\cline { 2 - 9 } lakuan & $2 \mathrm{MSP}$ & $4 \mathrm{MSP}$ & $6 \mathrm{MSP}$ & $8 \mathrm{MSP}$ & $2 \mathrm{MSP}$ & $4 \mathrm{MSP}$ & $6 \mathrm{MSP}$ & $8 \mathrm{MSP}$ \\
\hline $\mathrm{K}$ & $112,4 \mathrm{~b}$ & $225,3 \mathrm{~b}$ & $875,5 \mathrm{~b}$ & $875,5 \mathrm{~b}$ & $0,015 \mathrm{~b}$ & $0,050 \mathrm{~b}$ & $0,175 \mathrm{~b}$ & $0,175 \mathrm{~b}$ \\
JA2 & $306,6 \mathrm{a}$ & $625,0 \mathrm{a}$ & $1687 \mathrm{a}$ & $1687 \mathrm{a}$ & $0,045 \mathrm{a}$ & $0,188 \mathrm{a}$ & $0,403 \mathrm{a}$ & $0,403 \mathrm{a}$ \\
JB1 & $275,9 \mathrm{a}$ & $652,2 \mathrm{a}$ & $1851 \mathrm{a}$ & $1851 \mathrm{a}$ & $0,053 \mathrm{a}$ & $0,215 \mathrm{a}$ & $0,485 \mathrm{a}$ & $0,485 \mathrm{a}$ \\
JB2 & $283,9 \mathrm{a}$ & $689,7 \mathrm{a}$ & $1683 \mathrm{a}$ & $1683 \mathrm{a}$ & $0,043 \mathrm{a}$ & $0,215 \mathrm{a}$ & $0,368 \mathrm{a}$ & $0,368 \mathrm{a}$ \\
JD1 & $301,2 \mathrm{a}$ & $469 \mathrm{a}$ & $1657 \mathrm{a}$ & $1657 \mathrm{a}$ & $0,045 \mathrm{a}$ & $0,128 \mathrm{ab}$ & $0,418 \mathrm{a}$ & $0,418 \mathrm{a}$ \\
JE1 & $255,8 \mathrm{a}$ & $475 \mathrm{ab}$ & $2216 \mathrm{a}$ & $2217 \mathrm{a}$ & $0,055 \mathrm{a}$ & $0,165 \mathrm{a}$ & $0,508 \mathrm{a}$ & $0,508 \mathrm{a}$ \\
\hline
\end{tabular}

Keterangan : Angka-angka yang diikuti oleh huruf kecil yang sama pada kolom yang sama tidak berbeda nyata menurut DMRT 5\%.

Pemanjangan akar yang semakin baik berdampak pada peningkatan bobot kering akar. Perlakuan isolat memiliki akar yang lebih panjang dan banyak, sedangkan kontrol memiliki akar lebih pendek dan sedikit (Gambar 1). Semakin panjang dan banyak suatu akar, maka bobot kering akar akan meningkat. Menurut Rahni (2012), IAA merupakan salah satu golongan auksin yang berperan dalam memacu pertumbuhan akar tanaman, sehingga berakibat pada meningkatnya bobot kering akar. 

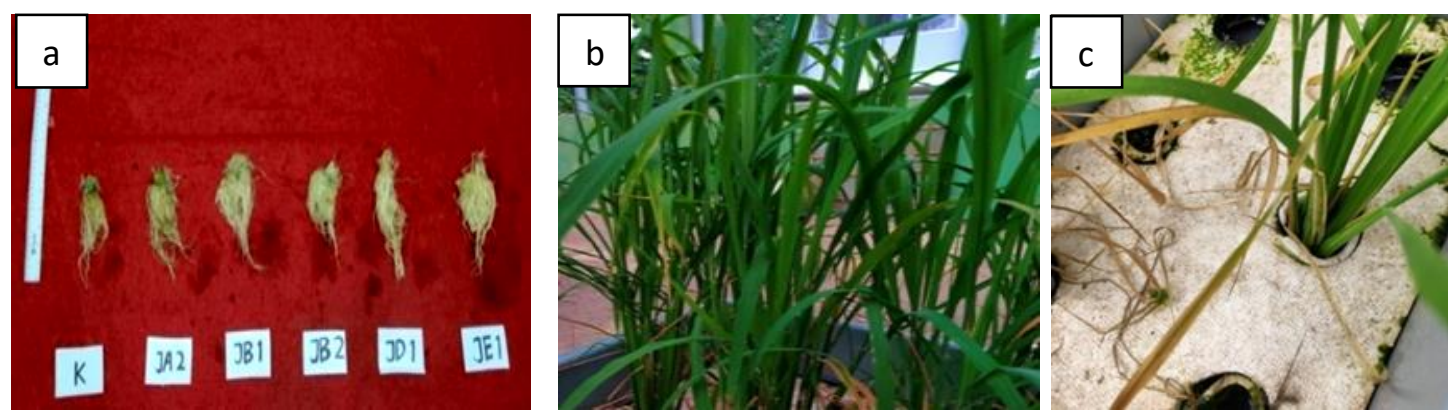

Gambar 1. Perubahan morfologi tanaman padi pada medi salinits tinggi a. Perakaran tanaman padi yang diinokulasi PGPR dalam kondisi salinitas tinggi. b.tanaman yang diinokulasi PGPR tampak lebih hijau. c. tanaman padi tanpa inokulasi PGPR

Meningkatnya bobot kering dan luas permukaan akar mengakibatkan penyerapan hara dan air yang penting untuk proses fotosintesis meningkat, tanaman dengan inokulasi isolat PGPR menunjukkan pertumbuhan daun lebih luas dengan warna lebih hijau (Gambar 2). Inokulasi isolat PGPR indigenous Inokulasi isolat PGPR dapat meningkatkan kehijauan daun sebesar $19 \%$ dan luas daun sebesar 50 $\%$ pada pengamatan $8 \mathrm{msp}$. Oktavia \& Maghfoer (2018) menyatakan bahwa rizobakteri yang mengkolonisasi akar mampu memfiksasi nitrogen di atmosfer menjadi bentuk yang dapat dimanfaatkan oleh tanaman. Nitrogen berperan dalam meningkatkan luas daun tanaman. Tanaman yang tercukupi kebutuhan hara nitrogen mempunyai kandungan klorofil daun yang tinggi, sehingga dapat memproduksi asimilat untuk menyokong pertumbuhan pada fase vegetatif. Setiyowati et al. (2012) menambahkan bahwa peningkatan luas daun dan peningkatan warna daun menjadi hijau mengindikasikan terjadinya peningkatan kadar klorofil yang berperan dalam pembentukan fotosintat untuk mendukung pertumbuhan dan perkembangan tanaman.

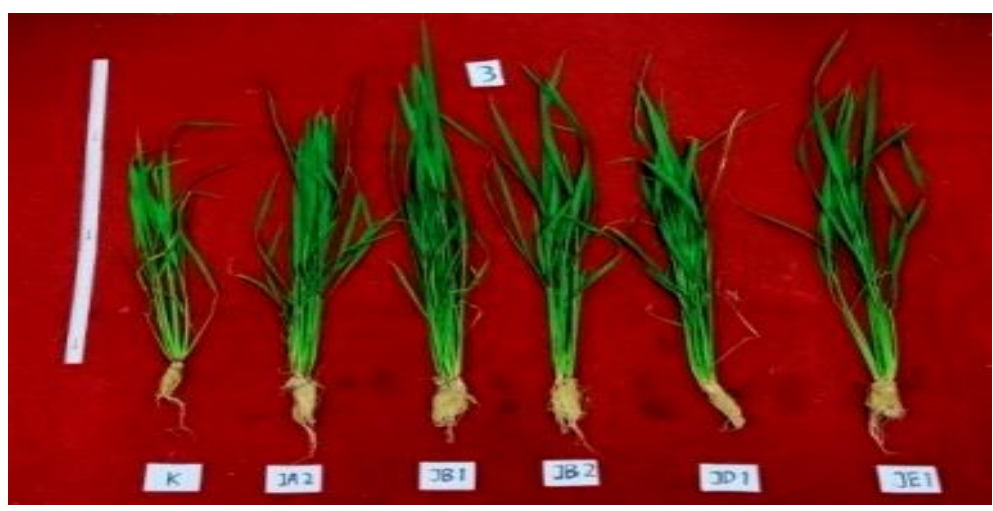

Gambar 2. Hasil Pengamatan Tinggi Tanaman K (b) Isolat JA2 (c) Isolat JB1 (d) Isolat JB2

(e) Isolat JD1 (f) Isolat JE1

Tanaman kontrol tanpa perlakuan inokulasi isolat PGPR pada media dengan salinitas tinggi menunjukkan gejala daun mengering, menguning (Gambar 1a) dan 
berakibat pada menurunnya kadar klorofil (Tabel 2). Hal ini disebabkan kadar garam tinggi yang terserap akar tanaman akan menghambat sistem kerja dalam pertumbuhan seperti menurunnya kadar klorofil untuk proses fotosisntesis. Kelimpahan ion $\mathrm{Na}+$ dan $\mathrm{Cl}$ - menyebabkan keterganggunya penyerapan beberapa unsur seperti N, P, K dan Mg oleh tanaman (Sulasih \& Widawati, 2016). Ma'ruf (2016) menyatakan bahwa tanaman yang tercekam garam akan mengalami toksisitas garam dikarenakan konsentrasi ion yang tinggi dan kekurangan air akibat dari lingkungan yang hipertonis. $\mathrm{Hal}$ ini mengakibatkan tanaman mengalami kekeringan. Adaptasi yang dilakukan dalam kondisi tercekam garam yaitu menurunkan kadar klorofil. Penurunan kadar klorofil sejalan dengan peningkatan konsentrasi garam. Menurut Maulina \& Darmayasa, (2018), PGPR mampu meningkatkan kadar klorofil. Gholami, Shahsavani, \& Nezarat (2009), menyatakan bahwa tanaman yang diinokulasi PGPR menunjukkan peningkatan luas daun. Meningkatnya luas daun akan memungkinkan tanaman mampu menggunakan semua cahaya untuk melangsungkan proses fotosintesis (Sirait, 2008). Akar tanaman yang panjang dan tingginya asimilat yang dihasilkan mengakibatkan pertumbuhan tanaman semakin baik dikarenakan akar tumbuh opimum sehingga dapat menyerap nutrisi dan air lebih banyak. Air dan nutrisi akan diserap untuk selanjutnya ditransportasikan oleh xylem menuju seluruh tubuh tumbuhan termasuk daun untuk membentuk klorofil. Helai daun yang luas disertai peningkatan kandungan klorofil akan meningkatkan pembentukan karbohidrat melalui proses asimilasi karbon. Karbohidrat sebagai hasil fotosintesis akan didistribusikan ke organ penyimpanan baik berupa bobot kering tanaman maupun mengubah menjadi hasil ekonomi merupakan hal yang sangat penting untuk peningkatan hasil tanaman baik hasil biologis maupun hasil ekonomis (Mastur, 2016)

Tabel 2. Pengaruh inokulasi PGPR indigenous lahan salin terhadap kadar klorofil dan luas daun padi.

\begin{tabular}{cllllllll}
\hline \multirow{2}{*}{ Perlakuan } & \multicolumn{4}{c}{ Kehijauan Daun (unit) } & \multicolumn{3}{c}{ Luas Daun Total $\left(\mathrm{cm}^{2}\right)$} \\
\cline { 2 - 9 } & $2 \mathrm{MSP}$ & $4 \mathrm{MSP}$ & $6 \mathrm{MSP}$ & $8 \mathrm{MSP}$ & $2 \mathrm{MSP}$ & $4 \mathrm{MSP}$ & $6 \mathrm{MSP}$ & $8 \mathrm{MSP}$ \\
\hline K & $24,58 \mathrm{~b}$ & $31,25 \mathrm{~b}$ & $34,53 \mathrm{c}$ & $34,53 \mathrm{c}$ & $5,30 \mathrm{~b}$ & $8,67 \mathrm{~b}$ & $25,87 \mathrm{c}$ & $38,46 \mathrm{~b}$ \\
JA2 & $32,38 \mathrm{a}$ & $38,85 \mathrm{a}$ & $38,40 \mathrm{~b}$ & $38,40 \mathrm{~b}$ & $13,94 \mathrm{a}$ & $22,73 \mathrm{a}$ & $39,8 \mathrm{ab}$ & $48,8 \mathrm{ab}$ \\
JB1 & $32,18 \mathrm{a}$ & $41,08 \mathrm{a}$ & $41,3 \mathrm{ab}$ & $41,2 \mathrm{ab}$ & $13,36 \mathrm{a}$ & $26,77 \mathrm{a}$ & $50,43 \mathrm{a}$ & $62,21 \mathrm{a}$ \\
JB2 & $31,83 \mathrm{a}$ & $39,70 \mathrm{a}$ & $41,98 \mathrm{a}$ & $41,98 \mathrm{a}$ & $14,25 \mathrm{a}$ & $24,87 \mathrm{a}$ & $40,5 \mathrm{ab}$ & $58,77 \mathrm{a}$ \\
JD1 & $31,03 \mathrm{a}$ & $38,15 \mathrm{a}$ & $42,60 \mathrm{a}$ & $42,60 \mathrm{a}$ & $12,68 \mathrm{a}$ & $23,15 \mathrm{a}$ & $37,65 \mathrm{~b}$ & $60,96 \mathrm{a}$ \\
JE1 & $32,88 \mathrm{a}$ & $39,15 \mathrm{a}$ & $41,80 \mathrm{a}$ & $41,80 \mathrm{a}$ & $15,55 \mathrm{a}$ & $24,83 \mathrm{a}$ & $49,73 \mathrm{a}$ & $56,54 \mathrm{a}$ \\
\hline
\end{tabular}

Keterangan : Angka-angka yang diikuti oleh huruf kecil yang sama pada kolom yang sama tidak berbeda nyata menurut DMRT 5\%

Inokulasi PGPR indigenous lahan salin mampu meningkatkan bobot kering tajuk dan bobot kering total tanaman dibandingkan dengan kontrol, tetapi antar isolat tidak ada perbedaan pengaruhnya sampai pada pengamatan 8 MSP. Inokulasi isolat dapat meningkatkan bobot kering tajuk sebesar $130 \%$ dan bobot kering total 
sebesar $131 \%$ pada pengamatan $8 \mathrm{msp}$. Pengaruh inokulasi PGPR indigenous lahan salin terhadap bobot kering tajuk dan bobot kering total (Tabel 3.)

Tabel 3. Rerata bobot kering total dan tajuk pada perlakuan inokulasi PGPR di medium dengan salinitas tinggi

\begin{tabular}{ccccccccc}
\hline \multirow{2}{*}{ Perlakuan } & \multicolumn{3}{c}{ Bobot kering Tajuk (g) } & \multicolumn{3}{c}{ Bobot kering Total (g) } \\
\cline { 2 - 9 } & 2 MSP & 4 MSP & 6 MSP & 8 MSP & 2 MSP & 4 MSP & 6 MSP & 8 MSP \\
\hline K & $0,13 b$ & $0,43 c$ & $1,01 b$ & $1,01 b$ & $0,14 b$ & $0,48 d$ & $1,19 b$ & $1,19 b$ \\
JA2 & $0,29 a$ & $1,20 a$ & $1,95 a$ & $1,95 a$ & $0,33 a$ & $1,39 b c$ & $2,36 a$ & $2,356 a$ \\
JB1 & $0,31 a$ & $1,51 b$ & $2,30 a$ & $2,30 a$ & $0,37 a$ & $1,72 a$ & $2,78 a$ & $2,78 a$ \\
JB2 & $0,25 a$ & $1,23 a b$ & $2,30 a$ & $2,30 a$ & $0,29 a$ & $1,44 a b$ & $2,67 a$ & $2,67 a$ \\
JD1 & $0,28 a$ & $0,93 b$ & $2,41 a$ & $2,41 a$ & $0,32 a$ & $1,06 c$ & $2,83 a$ & $2,83 a$ \\
JE1 & $0,31 a$ & $1,17 b$ & $2,61 a$ & $2,61 a$ & $0,37 a$ & $1,34 b c$ & $3,12 a$ & $3,12 a$ \\
\hline
\end{tabular}

Keterangan : Angka-angka yang diikuti oleh huruf yang sama pada kolom yang sama tidak berbeda nyata menurut DMRT 5\%.

Isolat PGPR yang mengkolonisasi akar, mampu menghasilkan IAA yang menstimulasi pemanjangan dan memperluas luas permukaan sehingga serapan hara lebih tinggi dan memacu pertumbuhan tinggi tanaman (Fitriati et al., 2009). Inokulasi isolat PGPR indigenous lahan salin mampu meningkatkan tinggi tanaman dibandingkan dengan kontrol, tetapi antar perlakuan isolat tidak memberikan pengaruh yang berbeda pada pengamatan $4 \mathrm{msp}, 6 \mathrm{msp}$, dan $8 \mathrm{msp}$. Hasil pengamatan 2 msp menunjukkan pengaruh perlakuan isolat JE1 tidak berbeda dengan perlakuan JA2 dan JB1, sedangkan pengaruh isolate JB2 tidak berbeda dengan JD1. Inokulasi isolat dapat meningkatkan tinggi tanaman hingga $21 \%$ pada pengamatan $8 \mathrm{msp}$ (Tabel 4). Hasil pengamatan tinggi tanaman sesuai dengan pernyataan (Yanti et al., 2019) mampu menstimulasi pertumbuhan tanaman.

Tabel 4. Pengaruh Inokulasi PGPR Indigenous Lahan Salin terhadap Tinggi Tanaman Padi.

\begin{tabular}{cllll}
\hline \multirow{2}{*}{ Perlakuan } & \multicolumn{5}{c}{ Tinggi Tanaman Padi (cm) } \\
\cline { 2 - 5 } & $2 \mathrm{MSP}$ & $4 \mathrm{MSP}$ & $6 \mathrm{MSP}$ & $8 \mathrm{MSP}$ \\
\hline K & $34,83 \mathrm{~b}$ & $52,70 \mathrm{~b}$ & $67,60 \mathrm{~b}$ & $67,60 \mathrm{~b}$ \\
JA2 & $46,48 \mathrm{a}$ & $68,58 \mathrm{a}$ & $79,75 \mathrm{a}$ & $79,75 \mathrm{a}$ \\
JB1 & $44,60 \mathrm{a}$ & $69,55 \mathrm{a}$ & $83,33 \mathrm{a}$ & $83,32 \mathrm{a}$ \\
JB2 & $43,52 \mathrm{ab}$ & $68,40 \mathrm{a}$ & $80,55 \mathrm{a}$ & $80,55 \mathrm{a}$ \\
JD1 & $43,50 \mathrm{ab}$ & $67,45 \mathrm{a}$ & $79,43 \mathrm{a}$ & $79,43 \mathrm{a}$ \\
JE1 & $48,03 \mathrm{a}$ & $68,48 \mathrm{a}$ & $84,63 \mathrm{a}$ & $84,63 \mathrm{a}$ \\
\hline
\end{tabular}

Keterangan : Angka-angka yang diikuti oleh huruf kecil yang sama pada kolom yang sama tidak berbeda nyata menurut DMRT 5\%

Peningkatan tinggi tanaman adalah salah satu indicator meningkatnya pertumbuhan. Fotosintat yang dihasilkan berperan dalam meningatkan pertumbuhan tanaman, melalui peningkatan bobot kering dan penambahan tinggi tanaman. Menurut Zerrouk et al. (2019), PGPR menghasilkan IAA yang mengendalikan pertumbuhan tanaman, diantaranya pembelahan dan pembesaran 
sel yang mengakibatkan perubahan ukuran tanaman semakin tinggi. Tinggi tanaman merupakan bentuk pembelahan sel akibat adanya peningkatan asimilat dan sebagai indikator pertumbuhan. Menurut Saharan \& Nehra (2011), bahwa inokulasi PGPR mampu mensubstitusi pupuk, dan zat pengatur tumbuh, dan pestisida kimia, yang penting untuk proses pertumbuhan dan perkembangan tanaman.

\section{SIMPULAN}

1. Inokulasi isolat Plant-Growth Promoting Rhizobacteria yang berasal dari lahan salin mampu meningkatkan pertumbuhan tanaman padi pada fase vegetatif, tetapi belum terlihat perbedaan yang signifikan antar isolat.

2. Bobot kering tanaman, panjang akar, kehijauan daun, luas daun, tinggi tanaman masing-masing meningkat sebesar $130 \%, 108 \%, 19 \%, 50 \%, 21 \%$ dengan inokulasi PGPR pada medium dengan salinitas tinggi.

\section{UCAPAN TERIMA KASIH}

Penulis mengucapkan terimakasih kepada kepala Lab. Agronomi dan Hortikultura Fak. Pertanian UNSOED yang telah memfasilitasi peralatan dan bahan penelitian sehingga penelitian ini dapat terlaksana dengan lancar.

\section{DAFTAR PUSTAKA}

Anggarwulan, E. (2008). Physiological characters of kimpul (Xanthosoma sagittifolium (L.) Schott) in various of light intensity (shading) and water availability. Biodiversitas, Journal of Biological Diversity, 9(4), 264-268. https://doi.org/10.13057/biodiv/d09 0405

Arrosyid, H., \& Sugito, Y. (2018). Respon enam varietas tanaman tebu ( Saccharum officinarum L .) pada kondisi lingkungan cekaman garam. Jurnal Produksi Tanaman, 6(4), 678684.

Athallah, F.N.F., U. Dinar, B.N. Fitriatin, T. Simarmata. (2018). Synergism bioassay of selected indigenous halotolerant phosphorizobacteria from rice rhizosphere on saline soil ecosystem Synergism bioassay of selected indigenous halotolerant phosphorizobacteria from rice rhizosphere on saline soil ecosystem. IOP Conf. Ser.: Earth Environ. Sci, 205(012014).

https://doi.org/10.1088/1755-

1315/205/1/012014

Cahyaty, R.A.A., Aini, N. \& Sumarni, T., (2017). Pengaruh salinitas dan aplikasi bakteri rhizosfer toleran salin terhadap komponen hasil tanaman mentimun. Biotropika - Journal of Tropical Biology, 5(3), 133-137. https://doi.org/10.21776/ub.biotropi ka.2017.005.03.12

Dewi, T. K. (2015). Karakterisasi mikroba perakaran (PGPR) agen penting pendukung pupuk organik hayati. In PROS SEM NAS MASY BIODIV INDON. https://doi.org/10.13057/psnmbi/m0 10220

Fardhani, A.A., Simanjutak, D.I.N. \& Wanto, A. (2018). Prediksi harga eceran beras di pasar tradisional di 33 kota di indonesia menggunakan algoritma backpropagation. Jurnal Infomedia, 3(1). https://doi.org/10.30811/jim.v3i1.62 5

Fauzan, I.A. (2018). Keragaman bakteri penghasil indole acetic acid (iaa) dari 
persawahan salin Pantai Jetis. Universitas Jenderal Soedirman.

Fitriatin, B.N., A. Yuniarti, O. Mulyanti, F.S Fauziah, \& M.D. Tiara. (2009). Pengaruh mikroorganisme pelarut fosfat dan pupuk $p$ terhadap $p$ tersedia, aktivitas fosfatase, populasi mikroorganisme pelarut fosfat, konsentrasi $p$ tanaman dan hasil padi gogo ( Oryza sativa . L .) pada Ultisols. Jurnal Agrikultura, 20(3), 210-215.

Gholami, A., Shahsavani, S., \& Nezarat, S. (2009). The effect of plant growth promoting rhizobacteria ( PGPR) on germination, seedling growth and yield of maize. World Academy of Science, Engineering and Technology, 19-24.

Habibi, S., Djedidi, S., Ohkama-Ohtsu, N., Sarhadi, W. A., Kojima, K., Rallos, R. V., Yokoyama, T. (2019). Isolation and screening of indigenous plant growthpromoting rhizobacteria from different rice cultivars in afghanistan soils. Microbes and Environments, 34(4), 347-355. https://doi.org/10.1264/jsme2.ME18 168

Kurniahu, H., Sriwulan, S., \& Andriani, R. (2018). Pemberian PGPR indigen untuk pertumbuhan kacang tanah (Arachis hypogaea L.) varietas lokal tuban pada media tanam bekas tambang kapur. Agrovigor: Jurnal Agroekoteknologi, 11(1), 52-57. https://doi.org/10.21107/agrovigor.v $11 \mathrm{i} 1.4305$

Kusumastuti, A. C., M. Kolopaking, L., \& Barus, B. (2018). Factors affecting the converstion of agricultural land in Pandeglang Regency. Sodality: Jurnal Sosiologi Pedesaan, 6(2). https://doi.org/10.22500/sodality.v6i 2.23234

Ma'ruf, A. (2016). Respon beberapa kultivar tanaman pangan terhadap salinitas. Bernas, 12(3), 11-19.

Mastur, (2016). Sinkronisasi source dan sink untuk peningkatan produktivitas biji pada tanaman jarak pagar. Buletin Tanaman Tembakau, Serat \& Minyak Industri, $\quad 7(1), \quad 52$. https://doi.org/10.21082/bultas.v7n1 .2015.52-68

Maulina, N.M.I., K. Khalimi, G.N.A.S. Wirya, D. N. S. (2015). Potensi rizobakteri yang diisolasi dari rizosfir tanaman graminae non-padi untuk memacu pertumbuhan bibit padi, J. Agric.Sci and Biotechmol 4(1), 1-8.

Maulina, N. M. I., \& Darmayasa, I. D. N. (2018). Pemanfaatan rizobakteri isolat Al7Kla untuk memacu pertumbuhan. DwijenAGRO, 8(2), 134-143.

Nghia, N.K., T.T.M. Tien; N.T.K. Oanh, \& N.H.K. Nuong. (2017). Isolation and Characterization of indole acetic acid producing halophilic bacteria from salt affected soil of rice-shrimp farming system in the Mekong Delta, Vietnam. Agriculture, Forestry and Fisheries, 6(3), 69. https://doi.org/10.11648/j.aff.201706 03.11

Oktaviani, T.J., \& M.D. Maghfoer. (2018). Respon pertumbuhan dan hasil tanaman pakcoy ( Brassica rapa L .) terhadap aplikasi EM dan PGPR. Jurnal Produksi Tanaman, 6(8), 1974-1981.

Rahni, N. M. (2012). Tanaman jagung ( Zea mays ). Jurnal Agribisnis Dan Pengembangan Wilayah, 3(16), 2735.

Saharan, B. S., \& Nehra, V. (2011). Plant growth promoting rhizobacteria: A Critical Review. Life Sciences and Medicine Research, 2011(1), 21.

Setiyowati, S., Haryanti, S., \& Hastuti, R. B. (2012). Pengaruh perbedaan 
konsentrasi pupuk organik cair tehadap produksi bawang merah (Allium ascalonicum L). Bioma: Berkala Ilmiah Biologi, 12(2), 44. https://doi.org/10.14710/bioma.12.2. 44-48

Shrivastava, P., \& Kumar, R. (2015). Soil salinity: A serious environmental issue and plant growth promoting bacteria as one of the tools for its alleviation. Saudi Journal of Biological Sciences, 22(2), 123-131. https://doi.org/10.1016/j.sjbs.2014.1 2.001

Sirait, J. (2008). Luas daun, kandungan klorofil dan laju pertumbuhan rumput pada naungan dan pemupukan yang berbeda. Jitv, 13(2), 109-116.

Subowo, Y. B. (2015). Penambahan pupuk hayati jamur sebagai pendukung pertumbuhan tanaman padi (Oryza sativa) pada tanah salin, PROS SEM NAS MASY BIODIV INDON 1(2007), 150-154.

https://doi.org/10.13057/psnmbi/m0 10126

Widawati, S. S. (2016). Pengaruh salinitas dan inokulasi bakteri terhadap petumbuhan tanaman terung (Solanum melongena L.), Berita Biologi 15(1): $17-25$

Yanti, Y., Hamid, H., \& Reflin, R. (2019). Indigenous rhizobacteria screening from tomato to control Ralstonia syzigii subsp. indonesiensis and promote plant growth rate and yield. Jurnal Hama Dan Penyakit Tumbuhan Tropika, 18(2), 177. https://doi.org/10.23960/j.hptt.2181 77-185

Yuliani, D. Z. (2011). penggunaan agen hayati rhizobium sp. dan pseudomonas fluorescens terhadap pertumbuhan tanaman kedelai (Glycine max) pada tanah salin
Retrieved from http://ejournal.unesa.ac.id/index.php /lenterabio

Zainudin, Abadi, A. L., \& Aini, L. Q. (2014). Pengaruh pemberian Plant Growth Promoting Rhizobacteria (Bacillus subtilis dan Pseudomonas fluorescens)terhadap penyakit bulai pada tanaman jagung(Zea mays L.). Jurnal HPT, 2(1), 11-18.

Zerrouk, I. Z., Rahmoune, B., Khelifi, L., Mounir, K., Baluska, F., \& LudwigMüller, J. (2019). Algerian Sahara PGPR confers maize root tolerance to salt and aluminum toxicity via ACC deaminase and IAA. Acta Physiologiae Plantarum, 41(6), 1-10. https://doi.org/10.1007/s11738-0192881-2 